\title{
The Archive, the Press and Victorian Football: the Case of the Glasgow Charity Cup [1]
}

\author{
Joyce Kay \\ University of Stirling
}

\section{Introduction}

'The past is a foreign country: they do things differently there.' [2]

The well-known opening line from L.P. Hartley's classic novel, The Go-Between, might easily be applied to the story of sports history, from its beginnings as an academic subdiscipline to its current state of play. If the subject matter of this article had appeared in print thirty years ago, it would probably have been presented as a simple narrative. What happened, to whom, when and where, and with what consequences would have unfolded in a straightforward, chronological fashion. Even in the 1970s the word 'antiquarian' might have been applied to a paper that outlined the origins of an early football cup competition as represented in the contemporary press and football authority yearbooks. It is possible that a critique of these sources might have been undertaken in an effort to lend credence to the mass of 'facts' uncovered. It is certainly to be hoped that our 1970s' scholar would have contextualised his research - it would almost undoubtedly have been 'his', female sports historians being virtually unknown in those days - within the development of amateur football and the Victorian city. It is unlikely that a rationale for his study would have been deemed necessary at a time when the whole field of sports history lay open to discovery.

The twenty-first century, however, is definitely another country. After over thirty years of outpouring on many sporting matters, present-day academics expect a more sophisticated approach. They want to see research justified, material analysed and assertions qualified. They look for more than traditional empiricism. Most significantly, they expect a discussion of the evidence, and, in particular, an interrogation of primary sources. Even when these are the best - and often the only - 'remnants of the past' that are available, they can no longer be assumed to represent 'the truth.' It would be unwise nowadays to raid the archive without an appreciation of Booth's strictures or mine the press without an awareness of Oriard and Hill's critiques. [3]

This article considers the foundation of a largely forgotten tournament, the Glasgow Charity Cup, in what was widely recognised as the nineteenth-century football capital of the world and places it within the context of the early Scottish association game. [4] It then attempts to evaluate the limited sources, paying close attention to how, and through which intermediaries, the information became available. Balancing the press against the archive in research terms, it is the newspapers, though often pursuing their own agendas, which seem to present the clearest picture of a murky past. Press coverage of organised Victorian association football in Scotland at a crucial time in its development reveals a previously unknown nexus between sport and charity, and highlights some difficulties encountered by an inexperienced, loosely-framed 'governing' body (the SFA) made up of relatively autonomous units (the clubs). The 'archive' 
belonging to that authority, on the other hand, eschews those difficulties and seems to display aspects of the manipulation, subjectivity and political interest of which such official sources have recently been accused. The SFA might even be considered guilty of a deliberate 'act of forgetting' in its references to the origins of the charity cup tournament although a less sceptical judgement would accept that gaps and omissions in the archive are almost inevitable - unfortunate but unintentional rather than politically motivated. [5] These differing perspectives will be brought to bear on evidence that must undoubtedly be weighed with care in the postmodern era. Ultimately, however, that evidence - fragmented, possibly partisan and frequently contradictory - is all we have; without it, there would be no history.

\section{The Background}

'in a very short time there arose in Glasgow ...various Clubs playing the Association Rules' [6]

Glasgow in the 1870s was a city of wealth and deprivation. It may have been known as the 'Venice of the North' because of its handsome Italianate buildings but 25 percent of its half a million citizens lived in one-roomed houses. [7] It may have been the 'second city of the Empire' and the sixth largest city in Europe but it was also reputed to be the most congested in Britain; Glasgow's death rate in 1878, fuelled by infectious diseases such as tuberculosis, was higher than that of London and most Scottish towns.[8] Its wealth had been founded in trade and now rested on shipbuilding, metalwork and engineering but the 1870s was a decade of industrial depression, compounded in 1878 by the collapse of the City of Glasgow Bank, one of the greatest financial scandals of the century. Sectors of the local economy, notably the building industry, were said to have been paralysed for several years thereafter, adding significant unemployment to the everpresent problems of disease and poverty. [9]

It was fortunate, therefore, that Glasgow had a large and expanding philanthropic sector. The year 1874 alone had seen the founding of the Western Infirmary, the East Park Home for Infirm Children, the Association for the Relief of Incurables and the Glasgow Public Dispensary; by the end of the century there were reckoned to be over 300 beneficent institutions and societies in the city. [10] These charities were private undertakings, wholly dependent on regular subscriptions, legacies and donations for their survival, and the annual balancing of income and expenditure was a difficult one. The unfavourable economic circumstances of the later 1870s put pressure on their budgets, attested to by the gloomy reports presented at annual general meetings. [11] At the same time efforts by the recently formed Glasgow Association for Organising Charitable Relief and Repressing Mendicity (the Scottish equivalent of the Charity Organisation Society in England) to rationalise the number of charities, minimise the distribution of handouts and promote self-help were not calculated to alleviate the distress of the urban poor. 'The virtue of self-reliance' and 'scientific' social enquiry had become watchwords of the later nineteenth century. [12] 
The application of 'science' was not restricted to the field of philanthropy, however, but allegedly played its part in the foundation of the SFA, soon to become a loyal and unflagging benefactor of Glasgow charities. Established in March 1873 'for the promotion of scientific football', SFA membership grew rapidly from eight founding clubs to 68 in season 1875-76, 90 percent of them located in Glasgow and the west of Scotland. [13] By 1879-80 the number had doubled to 140. One of the first projects of the infant Association was to promote a cup competition, won in its inaugural year (1874) by Queen's Park, the senior side in Scotland. In season 1878-79, 126 clubs entered the tournament; it took another four years for the English FA Cup to attract an entry of over 100. [14] The SFA also organised international matches with England and Wales, acted as rulemaker and arbiter in match disputes, and attempted to promote the association code but it took no part in arranging the club friendlies that formed the 'bread and butter' fixtures of the nascent Scottish football season. Nevertheless, by 1876 it had become, in the somewhat arrogant view of its Secretary,

a very prominent public institution and every event in connection with it was a public event towards which thousands looked with pleasurable anticipations and the consummation of which thousands joyfully congregated to witness. In these circumstances the Association Committee thought it a graceful as well as a rightful act, in return for this liberal public patronage, to close the season with a match for the benefit of some Charitable Institution. [15]

Thus, on 29 April 1876, teams representing Glasgow and Dumbartonshire took part in probably the first charity football game in Scotland on behalf of a benevolent organisation, the recently established Glasgow Western Infirmary. 'Although the season was virtually closed ... the public turned out manfully, and over $£ 100$ was handed over to the funds of the excellent institution.' It was hailed as one of the best matches of the season, with Glasgow winning 3-0 after 'some splendid play was shown on both sides.' [16] But this was not the start of the Glasgow Charity Cup; to begin with, there was no cup and, secondly, the charity cup contest was a club competition from the outset and one that took the form of a tournament whereas the 1876 match was a stand-alone game that included representatives from ten local sides. The following section will summarise what is known conclusively about Scotland's premier charity football event and attempt to disentangle the 'history' from the 'stories.'

\section{The Glasgow Charity Cup - Story and History}

'no competition of the kind in the kingdom can show such remarkable results' [17]

A brief outline of the Glasgow Charity Cup shows that it was first contested in April 1877 and thereafter annually until 1966, including the war years. Over this period it raised more than $£ 350,000$ (nearly $£ 11$ million in current prices) for city charities. The cup itself was bought for 100 guineas, and a further 50 guineas was spent on badges for the winning team members; it was therefore considerably more valuable than the SFA Challenge Cup, which, with badges, cost only $£ 56$ 12s 11d.[18] The fact that it is often referred to as the Glasgow Merchants' Charity Cup tells us something of its original 
sponsors; it was not, initially, conducted under the auspices of the SFA but was undoubtedly linked to the national football authority by the end of season 1878-79. [19] Before the advent of the professional game the record attendance at a match in Scotland was at a Charity Cup tie between Celtic and Renton in 1889 when at least 21,000 were present and, though far less prestigious than the Challenge Cup tournament in football terms, the final and often the earlier ties of the Charity Cup were still sufficiently important to be played at Hampden Park. [20] The major west of Scotland teams regularly took part; in the first five years these included Queen's Park, $3^{\text {rd }}$ Lanark Rifle Volunteers (Third Lanark), Rangers, Dumbarton and Vale of Leven. The competition was initially structured around two or three matches and expanded to five during the twentieth century but its status as a football tournament inevitably declined over time with the advent of the Scottish League in 1890, the League Cup in 1947 and finally with the arrival of European football in the 1950s. The oldest surviving charity football contest in Britain ceased in 1966, no longer able to persuade major Glasgow teams to take part. What is perhaps more surprising is that it continued to be played at all in the age of professionalism, particularly throughout an unbroken sequence of ninety years. [21]

Histories of the first English regional football associations demonstrate that the fame of the Glasgow Charity Cup in the late Victorian period reached far beyond the Scottish border. In managing to combine the two major components of a pre-league, amateur football season - the cup competition and the friendly - on behalf of charity, Glasgow clearly acted as a model for many similar competitions. Sheffield, the early heartland of English football which held 'an absolute key role' in the growth of the game, introduced the Wharncliffe Charity Cup competition in 1878 to be competed for by local FA clubs for the benefit of medical charities, following 'the custom in favour at Glasgow'. [22] N.L. Jackson, founder of the amateur Corinthians club, is said to have urged the Lord Mayor of London during the mid-1880s to present a trophy for competition amongst London clubs in imitation of Glasgow 'and it was hoped that a cup in the metropolis would be similarly successful.' It is also possible that Glasgow's early connections with the Birmingham FA led to the foundation of the Lord Mayor of Birmingham's Charity Cup in 1883. [23] By the early 1880s the historian of one English regional FA alleges that 'the major part of any club programme was devoted to charitable outlets.' [24]

This much is understood and uncontested in the history of the Glasgow tournament. What is less well known and more debatable is how, why and by whom it was started, at what point the SFA became involved in its management and why they did so. This is where 'history' turns to 'story'. The most popular version of events sees the cup mooted by a group of local merchants as a means of rapprochement between two feuding clubs, Queen's Park, founding member of the SFA and occupant of Hampden Park in the south of Glasgow, and Vale of Leven, formed in 1872 near Dumbarton, some 20 miles north of the city. Whether much credence can be given to this account may be judged from the following, based on conflicting secondary sources.

The two clubs had fallen out during 1875, allegedly because of a fixture cancelled at short notice, and thereafter refused to play each other. According to local football historians they either a) met in the semi-final of the 1876 SFA Cup, in which Vale was 
beaten or b) met in the final, with the same result or c) were scheduled to meet in the final until Vale refused to fulfil the tie, a much 'racier' story but sadly one with no basis in fact. [25] They are then said to have contested the 1877 Cup Final (wrong again) or alternatively - and more accurately - a fifth-round tie, with Vale victorious in either event (and, incidentally, inflicting the first ever defeat on the 'world-renowned' Queens' Park team) [26] After this match officials from the losing side apparently found spike marks in the pitch and accused their rivals of wearing illegal footwear. Press and historians alike report that the President and Secretary of Queen's Park later visited the homes of several Vale players to examine their boots, thereby exacerbating an already fraught relationship. [27] The feud between the clubs rumbled on throughout 1877 and was only settled at the end of the year.

These 'stories' raise a number of questions. Is there any evidence to suggest that club hostilities had a bearing on the foundation of the Glasgow Charity Cup? The historian of Queen's Park is convinced that the gentlemen who are alleged to have approached the club president in January 1877 to negotiate his team's participation in a new cup competition were intent on acting as peacemakers. The club selected to contest the first tie was not Vale of Leven, however, but Third Lanark, with whom the main instigator, and later chairman, of the Glasgow Charity Cup Committee, Lt. Colonel James Merry, was known to have connections. Why should these men, 'all interested in football', have cared enough about a club feud to attempt to re-establish cordial relations between two sides with whom they were not personally involved? There had to be a less expensive way of bringing the warring factions together than putting up 150 guineas for a cup and badges! [28] As for the SFA, it has already been noted that they lacked interest in purely domestic issues. As long as the recalcitrant clubs were prepared to play each other in SFA Cup ties - and they had contested the fifth round match in the 1877 competition the football authority was unlikely to be concerned in the matter.

An attempt has been made in the following pages to unravel fact from fiction by careful scrutiny of the press and the very limited archive, but these have only yielded a partial answer. Many 'stories' still peddled within Scottish football are contradictory and largely anecdotal but they are good 'stories' and will probably survive even in the face of a more accurate but less pithy and engaging account. (Indeed, as 'multiple narratives' they might be applauded by some within the academy). [29] When sporting myths are of little consequence and largely forgotten beyond the domain of the academic and the 'anorak', a definitive 'history' may scarcely matter. However, the charity football match, of which the Glasgow tournament was the pioneer, represents a key stage in the growth of the game, not only in Scotland but throughout Britain, bridging the gap between the foundation of football associations and the advent of leagues. [30] Of some concern to the historian is the way in which the 'stories' of its development have been created from dubious and unverifiable primary and secondary sources and it is therefore to traditional materials - the archive and the press - that we must turn in an effort to clarify the origins of the Glasgow Charity Cup. At the same time it has to be acknowledged that these are neither wholly unambiguous, uncomplicated documents nor intrinsically biased texts. 


\section{Interrogating the Archive}

'simple, straightforward sites of knowledge ...[or] ... sites of power.' [31]

Unlike the Football Association, the history of its Scottish counterpart has yet to be written. One reason for this omission may be that none of the early records of the association have survived: they were already missing in 1894. [32] The first SFA minute books, held at the Scottish Football Museum, Hampden, date from 1879: minute books for the Glasgow Charity Cup only begin in 1893. References to an earlier period, including the 1876 SFA-sponsored charity match in Glasgow, are contained in the SFA Annuals, a series of volumes spanning the quarter century from 1876-77 to 1899-1900. These constitute the 'archive' for the formative years of the Charity Cup. Published 'by authority and under the direction of the Scottish Football Association' and edited for the first four years by SFA secretary William Dick, these books contain a mixture of results, match reports, biographies of principal players and details of SFA-affiliated clubs, together with the laws of the association game, the rules, constitution and office bearers of the national football authority, and a number of articles on football matters.

Tantalisingly, one penned for the 1894-95 issue, on the twenty-first anniversary of the SFA foundation, reminisces on its early days and quotes at length from a letter book, no longer extant. It confirms that there are no minute books before 1879 and that the founding fathers still alive 'not being aware then that they were making history ... have allowed many things which would have been interesting to escape their memory.' [33] Those of a more Machiavellian disposition might wonder if this was deliberate.

In a recent defence of historians, historical methods and traditional sources, Martin Johnes has conceded that the archive can be 'a self-justifying and narrow view of decisions'. The SFA Annuals, therefore, might be nothing more than a selection of items that editors saw fit to include - or omit. [34] If, as he notes, the state can assemble material for its own purposes and decide what should be held, an authority such as the SFA can wield an analogous power within its limited fiefdom: the power to record, distort - intentionally or otherwise - or simply fail to publish details of its decisionmaking processes. As regards early charity football, the SFA secretary not only chose to leave out why, when and in what way the Association combined its efforts with those of the merchants but, by changing certain recording methods, made it very difficult to determine the 'facts'. The significance of editorial power can be demonstrated in the following example.

In the SFA Annual for 1879-80, the amounts collected for charity are set out as follows:

\section{Total contributions to charities}

1876 SFA and its affiliated clubs 
This seems to point to a distinction in 1877 and 1878 between funds collected by the SFA and its affiliated clubs and those gathered under the auspices of a Glasgow Charity Cup committee, with a joint arrangement from 1879. However, after the death of secretary William Dick, the AGM of the Association switched from autumn to spring and certain reporting procedures changed. Thereafter the same information is recorded thus:

\section{Total contributions to charities}

1875 SFA and its affiliated clubs

$£ 200$

1876 SFA, its affiliated clubs and Glasgow Charity Cup joint committees $\quad 380$

1877 SFA, its affiliated clubs and Glasgow Charity Cup joint committees $\quad 420$

1878 “ “ “

Not only does the date now reflect the start of the football year rather than the end, but from season 1876-77 all Glasgow Charity Cup contributions are listed under the banner of the 'joint committees', two years earlier than previously suggested. For some unknown reason the new SFA secretary, John McDowall, chose to ignore the apparent autonomy of the Glasgow Charity Cup committee in 1877 and 1878; this may have been an attempt to inflate the importance of the Association retrospectively, suggesting that no charity football, even in the beginning, took place outwith its control. The SFA certainly displays a tendency to self-aggrandisement in its early Annuals and the arrogance of its 1876 charity match announcement has already been noted. This reference begins by mentioning the striking 'increase in moral influence' of Scotland's football authority as it entered its fourth year and concludes pompously

The season was therefore the most successful that our Association has yet experienced, and it is a matter of great congratulation that the Scottish Football Association is the first Association of the kind that has linked itself with important public and benevolent purposes. [35]

It would undoubtedly have been a coup to add the Charity Cup to its portfolio as it became an increasingly prestigious event in the football calendar. Several pages of the post 1878 SFA Annuals are devoted to the tournament, not only providing short reports of the matches but lists of the yearly amounts raised and, for the first decade, the beneficiaries. Votes of thanks for the participating teams and the clubs that gave their grounds and stands free are also recorded. Looking back at the charitable contributions listed for the 1870s, however, no reader of a later SFA Annual would be aware that two separate authorities were involved in the organisation of charity matches during 1877 and 1878: the Association has erased the Glasgow Merchants' Charity Cup Committee and its pioneering role from football history. Instead the archive predictably portrays the SFA in the best possible light, one that exudes power, control and confidence.

\section{Interrogating the Press}

'there are many dangers in accepting at its face value the language of the sporting press.' [36] 
The most important source of information about early Scottish football in general and the Glasgow Charity Cup in particular is the local press. Glasgow boasted a thriving newspaper sector in the last quarter of the nineteenth century which included the Glasgow News, the North British Daily Mail, the 'quality' Glasgow Herald and its more populist sister paper, the Evening Times. All four have been consulted about the origins of the Glasgow Charity Cup; each has brought a different light to bear on the subject. The youngest, the Evening Times, launched in 1876, is said to have introduced a 'folksy' - we might say 'tabloid' - approach to the news and saw its sales climb rapidly to 50,000. [37] Of the four papers, it is the one that went beyond mere match reporting to campaign vigorously for charity football. The Herald, with a daily circulation of around 27,000 in the 1870s, covered games more extensively in its sports pages but printed the Evening Times' leaders about charity football verbatim in its morning editions. The Glasgow News, a Tory daily with a circulation of around 12,000, carried an extensive and sometimes vitriolic correspondence in early 1878 between the SFA and Vale of Leven in connection with the latter's non-appearance at a Glasgow Charity Cup tie that season. [38] The North British Daily Mail, forerunner of current Scottish tabloid, the Daily Record, started life in 1847 as the first 'penny daily'. Although it espoused popular liberalism, reporting trade union activities and exposing public scandals, its radical stance did not deter a significant middle-class readership. [39] It is the newspaper that reported most frequently, if briefly, on the AGMs and regular monthly meetings of the SFA.

Between them, the local papers provide a varied but often patchy coverage of football matters in general and the Glasgow Charity Cup in particular. An extensive list of fixtures in the Evening Times, often printed in the Saturday column of forthcoming afternoon and evening amusements rather than the sports page, was seldom matched by an equivalent number of results on the following Monday. [40] Reports on games were often short, the score invariably hidden away within the text; perhaps this typified an age in which winning was thought to be less important than taking part. It is also a period before the advent of a specialist sports press, as the British Saturday evening sports paper did not appear until the early 1880s. [41] With football reporting in its infancy during the previous decade, references to the first charity matches had much in common with descriptions of race meetings in the earlier part of the nineteenth century. It was as important to note who and what was there as to comment on the sport: compare the observation that 'a great number of fashionables were present every day' from The Scotsman's coverage of racing at Edinburgh in 1816 with the references to 'a large gathering among whom were many of our civic rulers and well known citizens' from a Glasgow Evening Times account of a charity match in1877. [42]

Newspaper reports in the week leading up to an important game provided publicity, built up interest and heightened tension amongst football fans. Before the first Glasgow Charity Cup contest readers were told that 'both clubs have been in active practice for this match' and that the cup, 'an elegant and massive piece of workmanship' was on view in the window of Mr. R Stewart, silversmith to the Queen. [43] A promenade before kick-off and a performance by the band and pipes of the $26^{\text {th }}$ Cameronians at half-time were advertised, contributing to the sense of occasion. When the trophy was presented by Glasgow's Lord Provost, before a crowd of 10-12,000 
according to the Glasgow Herald, he congratulated the teams for displaying a worthy manifestation of muscular Christianity in aid of the benevolent institutions of the city. The Evening Times agreed that there were at least 10,000 spectators including many ladies, gentlemen and members of the Town Council but noted that the match itself was 'not of an exciting nature.' [44]

Although such an event encouraged mutual congratulation and civic pride, the Glasgow press displayed far less of the whimsical journalism and 'anecdotal evidence' that Jeff Hill has commented on in relation to English cup competitions.[45] The reason for this is largely geographical. Both the SFA Challenge Cup and, more particularly, the Glasgow Charity Cup were contested by teams from the west of Scotland, often from within Glasgow itself. Although thousands descended on Hampden Park, which had become the preferred venue for international matches and cup finals, there was nothing comparable to the fabled 'road to London', on which fans from the north of England journeyed hundreds of miles to the alien south, often for the first time in their lives, to support their teams.[46] There was far less opportunity for newspapers to embellish the story, contrast the provincial with the metropolitan and bolster rival civic identities when so many of the clubs were located within the city and its suburbs. One of the few examples discovered in the Glasgow press of local 'bragging rights' concerns, yet again, that darling of Dumbartonshire, Vale of Leven. After they conquered the previously unbeaten Queen's Park in the 1877 fifth-round tie, readers of the Glasgow Herald were treated to a shortened version of the archetypal 'cup triumph', replete with late evening arrival of the train bearing the heroes, a station 'besieged' by crowds of wellwishers, and a shoulder-high procession of the players.[47]

The way in which the Glasgow press covered football matches in the 1870s was factual, predictable and relatively dull, and it seems unlikely that the limited reporting of the association game in its early years would have contributed much to selling daily and evening newspapers. [48] The publishing of Vale of Leven's vitriolic correspondence with Queen's Park and a later dispute with the SFA, together with the opinions generated by these issues in the letters columns, constitute the most exciting language used about football in this period. Without a dedicated sporting press and with hyperbole limited to the size and quality of the crowd and the atrocity of the weather conditions, there is probably less to fear from a reliance on newspaper evidence than might be the case in years to come.

In one respect, however, the local press matched the SFA's high opinion of itself and its influence on Glasgow life. Following two outspoken leading articles in the Evening Times during March 1877 on the subject of football and charity, the Glasgow Herald report of the inaugural charity cup final credits its stablemate with helping to foster the competition. It states that 'the movement which resulted in the institution of these matches originated, as will be remembered, in a suggestion thrown out in the columns of the Evening Times.' To what extent this was true may be gauged from a more detailed history of the early charity football movement and of the available sources. [49]

\section{The Glasgow Charity Cup - The Story Continues}


'something should be said to account for that apathy towards, and want of liberality shown to, deserving institutions by successful football clubs' [50]

The Evening Times had only been in print for a matter of months and was perhaps seeking to make its mark as a 'campaigning' newspaper when the following three items appeared. These present an alternative version of the charity tournament origins and allude to issues that were to plague Scottish football for more than a decade: gate money and professionalism. In the first, entitled Football clubs and their gate money, dated 9 March 1877, a leading article drew attention to the large sums that were regularly collected at club matches and asked to what ends these takings were applied. Football was an amateur game, therefore no wages were paid, and although costs were incurred in renting grounds and defraying out-of-pocket expenses, the paper estimated that these probably amounted to only $£ 100$ per season. Advertisements in the press suggest that $6 \mathrm{~d}$ was normally charged for entry, rising to $1 \mathrm{~s}$ for the most important matches. What happened to the gate money realised from attendances of up to 6,000? [51] The Evening Times stopped short of implying that club officials were lining their own pockets gentlemen connected with clubs 'are above suspicion in monetary matters' - but 'certainly none of it finds its way to the upholding or strengthening of our charitable institutions and we look in vain for the subscription of any of the clubs in the annual reports of our deserving and struggling charities.' [52] This piece was reprinted in its entirety in the Glasgow Herald the following morning.

A week later, a further article appeared under the heading Football clubs and what they might accomplish. Not content with castigating clubs for their lack of charity, it launched a thinly veiled attack on the SFA itself.

It is ... very noticeable that towards the fag-end of each season there is a great blowing of trumpets as to the benevolent intentions of those having a say in the arrangement of matches for charitable purposes but we fear more can be said as yet in commendation of good intentions than in the accomplishment of the object sought to be achieved. [53]

It regretted that those who spent so much energy organising exhibition trials of the Probables and the Possibles for international matches against England and Wales - that is, the SFA - could not make the effort to persuade popular clubs such as Queen's Park or Vale of Leven 'to combine in providing some struggling institution with the necessary capital to enable it to close the year's accounts with a smaller deficit.' [54] While it was glad to see that the SFA had arranged several charity matches, it felt that these endeavours could be backed up by individual clubs and private arrangements. [55] It concluded as follows

These are suggestions we venture to throw out just now so that during the course of next season something may be done towards enlisting the sympathy, enthusiasm and support of the football public in those contests having for their object the augmentation of the funds of deserving and charitable undertakings. 
The Evening Times did not have to wait long for a response; perhaps it had acted disingenuously, being already in possession of information which went some way towards achieving its aims. A postscript to the leader of 17 March hinted that since publication of its original comments the week before, several gentlemen interested in football had subscribed money for a cup and that the subject was to be brought before the SFA immediately. The addition of this intelligence and the fact that these events appear to have taken place after publication of the critical article was clearly intended to reflect well on the paper and to suggest its influence and ability in getting things done. Indeed, matters must have been settled with extraordinary speed because the next issue of the Evening Times on Monday 19 March included a further item under the heading The football prize cup for city charities. This informed readers that a committee of a dozen gentlemen proposed to arrange a match between two of the most prominent clubs in the city for the benefit of local charitable institutions. This sounds remarkably similar to the proposal mentioned by the historian of Queen's Park; in his opinion, however, the arrangements were made in January 1877, some six weeks before the Evening Times 'campaign' on behalf of local charities. If the paper had heard rumours of the proposal, it could be accused of seeking publicity and credit for itself under false pretences but perhaps it was possible to devise, finance and implement a scheme for a cup competition within the ten-day period 9-19 March. In that case, the Evening Times may be credited with instigating the competition. There is no further evidence of these arrangements or the discussions leading up to them in the national football archives or in the newspapers. The issue of whether the Glasgow merchants decided spontaneously to fund a cup competition or whether they were influenced by the local press remains inconclusive.

There was a definite outcome, however, with the appearance of two prominent local teams in a match whose proceeds were to be devoted to charity, as both the paper and the sponsors had intended. In fact two matches were scheduled, the first between Queen's Park and Third Lanark and the second between the winners of this contest (Queen's) and the season's SFA Cup holders. These games, which took place in April 1877, constituted the first Glasgow Charity Cup competition: but there had already been a further twist to the tale. The SFA Cup final had been played between Rangers and Vale of Leven, with the Dumbartonshire side emerging as winners. Vale, with their usual intransigence, then refused to play the Charity Cup final because of their long standing dispute with Queen's. Rangers agreed to take their place, conceding four goals to Queen's Park, who therefore became the first winners of the Glasgow Charity Cup. The proceeds of the gate (£300) were divided between the Western and Royal Infirmaries, the decision having been taken by 'the committee of Glasgow Charity football matches.' [56]

This lengthy consideration of press coverage highlights a number of issues. Firstly it raises the question of gate money; if a match was not played for charity, what did clubs do with their profits? The Evening Times exonerates club members from fraudulent activities, concentrating on its campaign on behalf of charities but an anonymous article in the SFA Annual for 1880-81 (probably written by the SFA secretary who edited the volume) not only discusses 'the greed of gate-money' but also the 'sordid motives' of finance committees 
When I hear of clubs who have gathered ten, yea twenty times more than is required for such purposes ... [the payment of ground rent] ... deep in debt at the end of the season, I begin to wonder where all the money has gone. [57]

As the article is sub-titled 'Breakers Ahead - "the Professional", it leaves the reader under few allusions as to the perceived destination of the profits.

Secondly, the articles in the Evening Times suggest that permission was sought from the SFA before the Charity Cup tournament was finalised. Was this merely a courtesy gesture or did the Association wield sufficient power to veto the arrangements? Did it make any effort to involve itself in the competition at this early stage in its history or did 'he who paid the piper' - to the tune of 150 guineas for cup and badges - insist on overall control? Or, as this was a club fixture, was the SFA content to leave the organisation to others? As already noted, the governing body seemed more concerned with promoting the association game, arranging internationals and Challenge Cup fixtures, signing up new member clubs to increase both its coffers and its self-regard, and adjudicating on matters of law than on becoming more closely involved with individual clubs. It may have been aware that its authority could be challenged by any club with a mind to do so, as will be shown later.

Having dealt with the matter of how and when the Glasgow Charity Cup began, the question remains as to why and when the new competition ceased to be independent of the SFA. Before examining the evidence, a few possibilities should be considered. From the merchants' standpoint, it may be that their initial experience of dealing with uncooperative football clubs discouraged the committee from attempting to organise the tournament unaided the following year. The uncompromising attitude displayed by Vale of Leven introduced a rather unseemly element to an event that was supposed to reflect generosity, good fellowship and a selfless attitude towards others. Vale had allowed their longstanding private dispute with Queen's Park to spill over into the fledgling cup competition. By refusing to take part, at a time when 'taking part' was said to be an important facet of any sporting contest, they sullied the enterprise yet escaped without punishment. If the format of the Glasgow Charity Cup remained the same, that is, the winner of an initial tie playing the SFA cup holders in a final, Vale and Queen's Park, who were amongst the most successful clubs in Scotland, might meet again in 1878. (Vale went on to win the SFA Cup in both 1878 and 1879.) But by bringing the tournament under the umbrella of the SFA, perhaps sanctions could be imposed on recalcitrant sides; they could, for example, be excluded from any SFA-sponsored competition.

On the other hand, it is possible that the national administration was unwilling to tolerate a cuckoo in its nest. The Glasgow Charity Committee was an alternative, albeit limited, power in football: it could be viewed as undermining the authority of the Association. Teams entered its competition initially by invitation. There was nothing to prevent it from expanding the knockout round as it was free to negotiate with any SFAaffiliated club; it was only for the final tie that the committee depended on the 
cooperation of the Challenge Cup holder. The SFA may also have harboured some jealousy towards the merchants. Not only was their cup more than twice as valuable but the proceeds of the two 1877 charity tournaments were stacked heavily in favour of the new competition. ( $£ 130$ raised by the SFA representative match as against $£ 300$ for the Charity Cup).

\section{The Glasgow Charity Cup - Death and Transfiguration}

'The Glasgow Charity Football Committee handed over their handsome Cup (valued at upwards of 100 guineas) to the management of the SFA, with three members from their Committee. Owing to various circumstances the programme proposed by the Committee was not fully carried out.' [58]

With this terse statement the independent life of the Glasgow Charity Cup committee came to an end. There is no indication of the date when this occurred, what the programme might have been or why it was aborted. By using the symbolism of the trophy it is not even made clear if the SFA was thenceforth in charge of the tournament; it is not certain which committee was unable to carry out its programme. Nor is there any reference in the Annual of 1878-79 to an SFA-promoted representative match as in the previous two seasons: presumably this was abandoned and never resurrected. Without minute books for this period, the SFA silence on these matters is deafening and the press is equally taciturn on issues of football administration and control. Using press coverage of football matters only - in the absence of any other sources - an attempt will be made to establish what happened in the period from the final of the first Glasgow Charity Cup in spring 1877 to the middle of the following year.

On 22 October 1877 over 200 men were killed at the Blantyre Pit in Lanarkshire, one of the worst mining disasters in British mining history, and a week later the Evening Times announced that the SFA was trying to arrange a match for the benefit of the widows and children. [59] Correspondence between William Dick, SFA Secretary, and Vale of Leven, published some months later in the Glasgow News, indicates that Vale were asked to play Queen's Park in this charity fixture. Charity was expected all round: the match was intended to effect a reconciliation between the clubs and, perhaps to make refusal more awkward, the game was surprisingly designated as the first tie of the 'Merchants Charity Cup.' [60]

It was the end of November before the SFA announced that it had arranged a fixture between the two, 'the differences which had existed between these clubs having now been settled'. [61] What followed next bordered on farcical. Vale became embroiled in a dispute with Rangers over a disallowed goal in an SFA cup tie and, when the Association confirmed that the two would have to replay, it refused to take part in the charity match until the cup-tie was decided. As this could not be played until 15 December, Third Lanark was invited to contest the Blantyre match instead. On the appointed day, 8 December, bad weather caused the postponement of the game; it was postponed again on 22 December and never took place, the SFA donating a meager £15 to the colliery relief fund instead. In the meantime the SFA secretary asked Vale to 
reimburse the printing and bill posting costs relating to the aborted fixture. The club offered a $£ 5$ donation to the fund, pointing out that to pay expenses would be an admission of culpability when it was wholly innocent. The SFA returned the $£ 5$ to Vale, with the comment, 'the committee considered that it would only have been graceful on their part to have acceded to the committee's request.' [62] Letters continued to fly back and forth until the middle of March, with the spat conducted in full view of the Glasgow public. It cannot have helped the image of either the club or the Association and did nothing to uphold the latter's authority.

Worse was to follow. In early April the Glasgow News announced the 'first' tie for the Glasgow Charity Cup 'which is now under the management of the Scottish Association and a sub committee appointed by the subscribers,' to be played between Rangers and Third Lanark. [63] Before the game, Third Lanark 'intimated that they were averse to playing a cup tie after the tussle of the previous Saturday' - they had contested the SFA Cup final - and, because of numerous injuries, they fielded a weakened side. On 17 April three further ties were advertised in the press but ten days later, the Glasgow News informed its readers that the arrangements for the Charity Cup had fallen through as the clubs - Rangers, Queen's Park, Vale of Leven and Third Lanark - could not come to an agreement about the fixtures. Finally a match was played at Hampden between Queen's Park and Vale of Leven - the cupholders - at which about $£ 160$ was raised. The match report in the Evening Times ran to a mere seven lines; beneath it the proceedings of Rangers' AGM covered thirteen.

This six-month period marked the lowest point in the short history of the Glasgow Charity Cup. Not only had Vale of Leven, a perpetual thorn in the side of authority, refused to accede to SFA demands but Third Lanark, with connections to committee chairman Lt. Colonel Merry, had also refused to play ball. The power of the major clubs was amply demonstrated by the debacle of April 1878.

\section{Conclusion}

'this great institution was established, as shown in the Memorandum of Agreement, on the $1^{\text {st }}$ October 1877, and since then its course has been one of unbroken triumphs.' [64]

Ten years after the first Glasgow Charity Cup, the SFA published this statement in its Annual, finally establishing that the independent merchants' cup contest of April 1877 was held only once - presumably merger negotiations between the two interested parties took place during the summer of that year. The Scottish football authority observed that 'a sum very far in excess of any other organization of a similar nature' had been allocated to charity. It noted that there were ten names on the original document - unfortunately untraceable and presumed lost - and that the competition was the first and original 'of this new, great and good work ... with which the country now abounds.' [65] A decade on, the self-congratulatory tone is still evident but the early difficulties for the SFA have been obliterated. From a deconstructionist perspective, it looks as if political interests have been brought to bear on the archival material, ensuring that 'certain voices ... [in this case those of the merchants] ... are silenced and excluded.' [66] 
The preceding pages have sought to clarify the origins of the first, and certainly the most prestigious, charity football tournament in Britain, using the limited secondary sources available and, more particularly, the standard historical tools of archive and press. These have proved inadequate, giving rise to no more than reasoned speculation as to why the competition became a joint enterprise between local merchants and the national football authority. The early 'history' of the Glasgow Charity Cup remains conjectural, the notional tussles within and between the organisers and the clubs providing yet another 'story' in the annals of Victorian football. Yet there is something distinctly modern about administrators banding together in an effort to control powerful and recalcitrant clubs, if this is indeed what happened.

That such disagreements and ill feeling occurred before the 'scourge' of professionalism is perhaps surprising and raises the suspicion that money played a part in so-called amateur football at an earlier stage than previously supposed. The sources, deficient and dubious though they are, certainly suggest that Scottish football in the 1870s was already showing signs of the greed, internecine warfare and flouting of authority that were to be features of a later era, and that the newly-formed SFA struggled to control its members in the first decade of its existence. The story of the Glasgow Charity Cup may even be a microcosm of the nascent game north of the border. A virtually exclusive concentration on religion and ethnicity, and on the fortunes of Rangers and Celtic, however, means that no comprehensive history of Scottish football has yet been attempted. Only when this is finally written can issues raised above - the 'amateur' status of the early game, the power of clubs in relation to the SFA, the relationships between local rivals - be more satisfactorily resolved. Such an outcome, however, is dependent on the evidence, and efforts in this paper to make sense of partial and contradictory historical fragments suggest that this may not be an easy task. To 'discover the intentions of the author of each and every source or text' would require yet more conjecture about what drove Victorian Scotsmen to take up, organise, disseminate and develop the game of football. [67]

With reference to the Glasgow Charity Cup, the press has supplied useful insights into the petty bickering between clubs and authorities but the maxim that 'good news doesn't sell newspapers' should alert us to one of many possible problems with too great a reliance on this source. Readers of the Glasgow Times avidly followed the dispute between the SFA and Vale of Leven through its letter columns and 'had their say' - like callers to the ubiquitous twenty-first-century football phone-ins. The correspondence was allowed to run for over eight weeks. But who decided which, how many and for how long letters should be printed? Whose 'Outraged of Dumbarton' responses never made it into print? An editorial hand manipulated and constructed the difference of opinion until the matter ceased to be news, just as the leader writer in the Glasgow Evening Times decided to take up his pen in favour of the charitable institutions of the city and against both the greedy football clubs and the pompous SFA. His motive, suggested above, may have been a publicity campaign that would reflect positively on the recently launched paper and perhaps increase awareness and sales. Newspapers, after all, are commercial 
enterprises and as Leonard Koppett also observed, 'Every story starts with a perspective.' [68]

A greater dependence on the archive instead is not necessarily the way forward, even assuming that sufficient documents are available for scrutiny. In the case of the Glasgow Charity Cup, an absence of SFA minutes, correspondence or other suitable material led to a reliance on 'edited highlights' in the form of an annual publication of football matters, chosen by the secretary of the organisation. Although early volumes acknowledged the role of local merchants in supporting charity competition, a new administrator, John McDowall, sought to accentuate the philanthropic efforts of his masters and simply omitted the pioneering endeavours of the rival group. Any early 'history' of the SFA is likely to be dependent on the documents he chose to retain - he held the post for over twenty-five years. The archive, in such a case, is reduced to the whim of an individual.

The historian who attempts to tell the story - or stories - of Scottish football will face many difficulties. The practical problems of evidence will be compounded by the many issues touched on in this paper: interrogating the sources, pondering the motives of key personnel, assessing whose interests were served in the recording of 'facts', the preserving of documents or the silencing of actors in the drama. It could be a lengthy but entertaining task.

\section{Notes}

[1] The author is grateful to the Nuffield Foundation for research opportunities, the staff of the Scottish Football Museum for their patient assistance, and Wray Vamplew for helpful comments on an earlier draft.

[2] L.P. Hartley, The Go-Between (London, 1953), p.7.

[3] For recent criticism of historical sources, see Douglas Booth, The Field: Truth and fiction in sport history (London, 2005), especially Chapter 5, 'Remnants of the Past'; Jeff Hill, 'Anecdotal Evidence: Sport, the Newspaper Press and History' in Murray G.

Phillips, ed., Deconstructing Sport History: A Postmodern Analysis, (Albany, NY, 2006), pp.117-129; Michael Oriard, 'A Linguistic Turn into Sport History' in Phillips, Deconstructing Sport History, pp.75-91; Douglas Booth, 'Sites of Truth or Metaphors of Power? Refiguring the Archive', Sport in History, 26 (1) (2006), pp.91-109.

[4] D. Goldblatt, The ball is round: a global history of football (London, 2006) p. 68; Adrian Harvey, Football: the First Hundred Years (Abingdon, 2005), p.214; Bill Murray, The Old Firm: Sectarianism, Sport and Society in Scotland (Edinburgh, 1984), p.7.

[5] Booth, The Field, p.83, p.88.

[6] SFA Annual, 1876-77 (Glasgow, 1876), p.22. 
[7] Irene Maver, Glasgow (Edinburgh, 2000), p.125; Charles Withers, 'The demographic history of the city 1831-1911' in W. Hamish Fraser and Irene Maver eds., Glasgow, Vol II, 1830-1912 (Manchester, 1996), p.142.

[8] Charles A.Oakley, The Second City (London, 1947), introduction, p.149; S. G. Checkland, The Upas Tree: Glasgow, 1875-1970 (Glasgow, 1976), p.22; Maver, Glasgow, p.170; Glasgow Herald, 24 April, 1879.

[9] S. G. Checkland, Scottish Banking: a History 1695-1973 (Glasgow, 1975), p.471; W. Hamish Fraser, 'The working class' in Fraser and Maver, eds., Glasgow, p.320.

[10] John K. McDowall, The People’s History of Glasgow (Glasgow, 1899), p.64.

[11] General subscriptions to the Glasgow Convalescent Home at Lenzie fell in 1876, resulting in a deficit of $£ 384$, and it was 'unhappy' at having to encroach on its capital fund, Glasgow Herald, 17 January 1877; annual subscriptions to the Lock Hospital fell from $£ 575$ in 1876 to $£ 544$ in 1877 'chiefly attributable to the dulness of trade', Evening Times, 15 January 1878; at the AGM of the Glasgow Asylum for the Blind there were complaints of the 'dulness of trade and business which has prevailed for so long a period’, Evening Times, 21 January 1878.

[12] The Charity Organisation Society was said to be synonymous with much that was 'grudging, callous, dogmatic and reactionary', Benedict Nightingale, Charities (London, 1973) p111; an editorial in the Glasgow Herald, 12 February 1877, extolled the 'virtue of self-reliance'; the late Victorian 'scientific approach' to social enquiry, aimed at investigation of individual circumstances and eliminating overlap rather than doling out indiscriminate relief, eventually led to professional social work, Olive Checkland, Philanthropy in Victorian Scotland (Edinburgh, 1980), p.4, p.299.

[13] T.W.R. Johnston, 'The Scottish Football Association: Its Early Days' in John K. McDowall, ed., SFA Annual, 1894-95 (Glasgow, 1895), p.75 - italics added. The counties included in the west of Scotland are Ayrshire, Dumbartonshire, Lanarkshire and Renfrewshire.

[14] Matthew Taylor, The Association Game: A History of British Football (Harlow, 2008), p.41.

[15] SFA Annual, 1876-77, pp.26-7.

[16] Ibid, p.45. The report on p.27 of this volume states that the donation was exactly $£ 100$. An earlier friendly match had been held in Glasgow to raise funds for the victims of a fire in the district of Bridgeton (Evening Times, 17 March 1877).

[17] Richard Robinson, History of the Queen's Park Football Club 1867-1917 (Glasgow, 1920), p.181. 
[18] Johnston, 'Scottish Football Association’, p.79.

[19] The Evening Times first refers to the tournament as the Merchants' Charity Cup on 28 March 1877. See also Dave Twydell, Rejected F.C. of Scotland, Vol. 3 (Harefield, 1994?), p.215, p.255; and Rangers website, http://www.rangershistory.co.uk/competitions/charitycup.html, last accessed 15 July 2008.

[20] SFA Annual, 1889-90, p.83. The first Hampden Park, home of Queen's Park, included a permanent grandstand facility, built in 1876. See Simon Inglis, The Football Grounds of Great Britain (London, 1987), p.296. This would have made it particularly suitable for prestigious matches such as cup finals and international matches.

[21] Professionalism was finally sanctioned by the SFA in 1893. For further detail on the ninety years of the Glasgow Charity Cup, see Wray Vamplew, 'Remembering Us Year after Year: the Glasgow Charity Cup 1876 - 1966', Recorde, (forthcoming).

[22] Dave Russell, 'Sporadic and Curious': the Emergence of Rugby and Soccer Zones in Yorkshire and Lancashire, c. 1860-1914, International Journal of the History of Sport, 5

(2) (1988), p.190; Richard A. Sparling, The Romance of the Wednesday 1867-1926 (Sheffield, 1926), p.49.

[23] N.L. Jackson, Association Football (London, 1900), p.153; S.W. Clives, Centenary Book of the Birmingham County FA, 1875-1975 (Birmingham, 1975), p.36. In season 1878-79 Birmingham Calthorpe, Birmingham Aston Villa and a representative side from Birmingham and District FA all arranged matches against west of Scotland opposition.

[24] Ibid.

[25] SFA Annual, 1876-77, p.38; Twydell, Rejected F.C., p.264; Robinson, History of QPFC, p.178.

[26] Twydell, Rejected FC, p.265; Robinson, History of QPFC, p.95; Glasgow Herald, 2 January 1877.

[27] Twydell, Rejected FC, p.265; Robinson, History of QPFC, pp.96-8 cites the heated correspondence, published in the local press, that continued throughout January 1877.

[28] Robinson, History of QPFC, pp.178-9.

[29] Hill, 'Anecdotal Evidence', p.117; oral accounts of the 'spikes' incident were given to the author while undertaking research at the Scottish Football Museum, Hampden; Michael Oriard, Reading Football: How the Popular Press Created an American Spectacle (Chapel Hill, NC, 1993), quoted in Booth, 2005, p.94. 
[30] Joyce Kay and Wray Vamplew, 'Beyond Altruism: British Football and Charity 1877-1914', Soccer and Society, forthcoming 2010.

[31] Douglas Booth, 'Sites of Truth or Metaphors of Power? Refiguring the Archive', Sport in History, 26 (1) (2006), p.92.

[32] Johnston, 'Scottish Football Association', p.73.

[33] Ibid.

[34] Martin Johnes, 'Archives, Truths and the Historian at Work: A Reply to Douglas Booth's "Refiguring the Archive", Sport in History, 27 (1) (2007), p.131.

[35] SFA Annual, 1876-77, p.27.

[36] Jeffrey Hill, 'British Sports History: A Post-Modern Future?, Journal of Sport History, 23 (1) (1996), p.18.

[37] Joe Fisher, The Glasgow Encyclopedia (Edinburgh, 1994), p.248.

[38] 'The Vale' was said to have a 'leaning towards publishing official documents', having ratcheted up the earlier 'spikes' incident by divulging to the press the contents of letters between itself and Queen's Park. Robinson, History of QPFC, p.179.

[39] Ibid, p.244.

[40] see, for example, Evening Times, Saturday 3 February 1877, 70 matches, and Monday 5 February 1877, 15 results.

[41] Tony Mason, 'All the Winners and Half-Times', Sports Historian, 13 (1) (1993), p.6.

[42] The Scotsman, 10 October, 1816; Evening Times, 26 March 1877; Mike Huggins notes that lists of the 'company' at race meetings were often printed in local papers. Mike Huggins, Flat Racing and British Society 1790-1914 (London, 1914), p.42.

[43] Evening Times, 20 April and 27 April 1877.

[44] Glasgow Herald, 30 April 1877; Evening Times, 30 April 1877.

[45] Hill, ‘Anecdotal Evidence’, p.123.

[46] Inglis, Football Grounds, p.296, p.344.

[47] Glasgow Herald, 2 January, 1877. 
[48] This is not yet the age in which 'sport sells newspapers'. Hill, 'Anecdotal Evidence', p.121.

[49] There are other instances of press involvement in the launching of a charity cup competition but at a later date. The editor of The Football News in London organised the Southern Charity Cup competition for which the London Evening News purchased a trophy in 1900. Gamages Association Football Annual 1910-11(London, 1910), p.657.

[50] Evening Times, 9 March 1877.

[51] Queen's Park are said to have rented the first Hampden Park for only £20 a year, Inglis, Football Grounds, p.296. Even allowing for press exaggeration, many clashes between the best local teams regularly produced attendances of 2-3,000, cup ties probably more.

[52] Evening Times, 9 March1877.

[53] Evening Times, 17 March 1877.

[54] Does the naming of these two teams lend some credence to the idea, discredited earlier, that a rapprochement could be achieved by arranging a match between them for charity? Or were the names selected at random?

[55] After the success of the SFA-sponsored charity match in 1876, a second contest took place in March 1877 between representatives of the counties of Scotland and Glasgow. According to the SFA Annual, £130 was collected for the Home for Incurables, founded in 1875 'for people labouring under chronic or incurable disease.' (Checkland, Philanthropy, p.276) A letter in the name of its directors had been published in the Glasgow Herald on 15 March 1877 calling for additional funds and assistance from the general public. Whether this influenced the SFA's choice of charity is unknown. The Evening Times noted that the proceeds from the match amounted to $£ 12315 \mathrm{~s} 3 \mathrm{~d}$ but the SFA committee 'very handsomely added from their own funds a further sum of $£ 64$ s 9d.' Evening Times, 7 April 1877. No record has been found of additional SFA-sponsored charity matches in spring 1877.

[56] Evening Times, 4 May, 1877.

[57] 'Shall Association Football Die Out in Scotland? Breakers Ahead,' SFA Annual, 1880-81, p.15.

[58] SFA Annual, 1878-79, p.22.

[59] Evening Times, 29 October 1877.

[60] Glasgow News, 23 February 1878; an advertisement in the North British Daily Mail, 18 December 1877, announces that the match between Queen's Park and Third Lanark 
for the Blantyre Relief Fund is the first tie for this season's Merchants' Charity Cup. This seems to indicate that it is still considered to be the merchants' competition.

[61] North British Daily Mail, 26 November 1878.

[62] Glasgow News, 23 February 1878; correspondence between SFA and Vale of Leven from continues from 23 January to 18 March 1878.

[63] Glasgow News, 6 April 1878.

[64] SFA Annual, 1887-88, p.74.

[65] Ibid. Eighteen additional Scottish charity cup competitions were listed in this volume.

[66] Booth, The Field, p.85.

[67] Ibid., p.12.

[68] Quoted in Booth, The Field, p.90. 